\title{
Estetik tack! Estetisk kommunikation och konsten att lära
}

Ketil Thorgersen

Som solen över mig tvingar bort molnen försöker jag få min penna att skära fram ljusglimtar. Hur tänker jag egentligen? Vad är estetisk kommunikation? Blyertspennans färd över A4-blocket skapar svar; vägar som är tänkta $i$ vissa lager och potentiella $i$ andra. Jag sitter ute, solen värmer efter kall sommar och vinden viskar varma toner. Tyvärr är det inga svar alls att hämta i vindens viskningar . . . Pennan får gräva fram något.

Varför detta inledande stereotypt romantiska bladder? Här utlovas svar på vad estetisk kommunikation kan vara och tvingar läsaren att genomlida navelskådande klyschor innan den klara, tydliga och akademiska sanningen framskrider. Har det verkligen någon betydelse för läsaren att jag sitter mellan fågelskit på en parkbänk i solen och skriver? Behövs allt detta snick-snack för att förstå vad jag vill säga? Troligen inte, men helt klart är att textens form påverkar HUR texten förstås. Form och innehåll är två sidor av samma mynt; värdet på myntet får vi komma överens om sedan.

I sin avhandling Kreativitetsmysteriet ${ }^{\mathrm{I}}$, gör Daniel Ericsson en stor poäng av att standardformeln för akademiskt skrivande är en ärvd tröja från positivismen. Jag tänker att tröjan är one-size-fitsall som kommer i vitt och som håller armarna tryggt fångade på ryggen. Nästan ingen känner igen den som en tvångströja då vi har vant oss vid den. Vi har hjärntvättats till att se fördelarna med det torra logiska språket, gjutet i en förutbestämd, välbekant och förutsägbar struktur. Just nu bryter jag med detta, eller kanske

Hur du refererar till det här kapitlet:

Thorgersen, K. 20I8. Estetik tack! Estetisk kommunikation och konsten att lära. I: von Schantz, U., Thorgersen, K. and Lidén, A. (red.) De estetiska ämnenas didaktik Utmaningar, processer och protester. Pp. 3-23. Stockholm: Stockholm University Press. DOI: https://doi.org/Io.I6993/bap.a. License: CC-BY 
snarare böjer mitt skrivande runt de akademiska förväntningarna för att åstadkomma något mer - något som kan ackompanjera en komposition om estetisk kommunikation.

Jag ogillar verkligen begreppet “estetiska lärprocesser”. Jag vill hellre göra estetiska lärprotester än att använda detta oprecisa begrepp som godtyckligt ger intrycket av att i sig vara något eftersträvansvärt och bättre än annat lärande. Problemet är bara att vare sig innebörden av detta andra lärande eller begreppet "estetiska lärprocesser" sällan diskuteras och lyfts fram. Nu har tyvärr begreppet "estetiska lärprocesser" fastnat i det svenska språket, vilket gör att detta kapitel kommer inte kommer föreslå att vi störtar detta hegemoniska begrepp. Det ska bara utmanas och fyllas med lite innehåll. Detta kapitel kommer istället med ett förslag: Jag vill föreslå begreppet "estetisk kommunikation" som en möjlig didaktisk precisering av vad estetiska lärprocesser skulle kunna vara.

\section{Sats 1 - Sonat}

Detta kapitel står ostadigt på två begreppsliga pelare: Estetik och kommunikation. Båda är begrepp som har omhuldats och debatterats flitigt i såväl den pedagogiska som den filosofiska historien. Jag ämnar inte ge en särskilt uttömmande redogörelse eller diskussion av varken de filosofiska eller de pedagogiska debatterna kring dessa begrepp. Istället vill jag använda mig av några av de teoretiker som har inspirerat mitt tänkande kring detta; framförallt John Dewey ${ }^{2}$, Arne Næsss ${ }^{3}$ och Deleuze \& Guattari ${ }^{4}$. Med utgångspunkt i mina erfarenheter som elev, lärare, lärarutbildare, forskare, musiker och privilegierad vit, manlig samhällsmedborgare kommer jag bolla mina tankar mot dessa kloka mäns skrifter för att förhoppningsvis bidra med några nya eller annorlunda aspekter på estetik, lärande och kommunikation.

Jag börjar med estetik. "Hva i alle dager er estetikk for noe?» Frågan ställdes av mig som nyinvandrad norrman till Sverige för I 4 år sedan, men jag var på inget sätt först . . . Från att ha arbetat som lärare i olika ämnen, främst i musik i Stavanger, kom jag till Luleå för att skriva en doktorsavhandling om estetik och lärande. Där upptäckte jag snabbt att min (väl) dolda okunnighet om vad 
estetik kunde vara delades av många. Tydligen var estetikens väsen en såpass svår och grundläggande fråga att en hel egen gren inom filosofin befattat sig med att reda ut just detta5 ${ }^{5}$ Jag började läsa, naivt hoppfull om att $\mathrm{i}$ all denna text kunna hitta några goda svar. Svaren uteblev, men nya frågor uppstod snart: Vad är estetik i förhållande till konst? Hur ser relationen ut mellan kulturbegreppet och estetikbegreppet? Vad innebär det att använda estetikbegreppet som adjektiv - att något är estetiskt? Vad är en estetisk upplevelse/erfarenhet? Kan något sådant definieras? Finns estetik utanför erfarenheten? Och eftersom olika filosofer gav olika svar på alla mina frågor om estetik och konst blev svaren på vad en estetisk kunde vara, olika. Tala om lycka när jag hittade Richard Shustermans artikel The End of Aesthetic Experience ${ }^{6}$. Det var första gången jag stötte på någon som försökte reda ut flera av dessa frågor och som samtidigt gav mig en ingång till ett spår att följa som gav mening i förhållande till hur jag såg på lärande och konst. Shusterman ledde mig rakt in i armarna på John Dewey och hans texter om konst, estetik, lärande och demokrati.

John Dewey argumenterar i sina texter för att erfarenheter och kommunikation driver mänskligheten och den enskilda människan framåt. Kommunikation definieras av Dewey som delande av erfarenheter så att partikulära enskilda erfarenheter genom att delas utvecklas till nya gemensamma erfarenheter. John Dewey och Richard Shusterman räknas båda som pragmatiker. Det är viktigt att ta med i beräkningen att Dewey, James, Peirce, Mead och andra som grundade pragmatismen ${ }^{7}$ var djupt influerade av Charles Darwin och evolutionsteorin som precis började få ett allmänt genomslag. Vad Dewey beskriver är någon form av social och psykologisk evolutionsteori där utveckling av kunskap och sanning sker genom en selektionsprocess där den mest livskraftiga idén eller förklaringen överlever. På liknande sätt som när Darwin beskriver hur arterna utvecklas genom naturlig selektion, gradvisa förändringar och mutationer genom generationer, förklarar Dewey att en sanning förändras lite vid varje kommunikativt möte där människor delar sina erfarenheter och (miss)förstår varandra. Så som jag förstår detta är den avgörande utmaningen att vi människor besitter alltför trubbiga verktyg för kommunikation; vi är alltid beroende av att något medium så som skrift, tal, musik, 
bild, kläder (jag kan fortsätta länge), för att dela våra erfarenheter, upplevelser och funderingar. Kommunikation är med andra ord nästan omöjligt, men samtidigt helt nödvändigt. Kombinationen av en strävan efter att förstå, en längtan efter att inte behöva förändra sin syn på varat, och medieringens trubbighet leder till att människan och mänskligheten ständigt utvecklas. Enligt Dewey verkar det även som om det är utveckling i positiv bemärkelse - en evolutionär utveckling: Att allt blir bättre och bättre - åtminstone tills han upplevde andra världskriget och atombomben. Oavsett är det rimligt att se John Deweys pragmatism som något av en förvarnare till den relativa sanningssyn som kom att råda i och med framväxten av postmodernismen där synen på sanningen blir att sanningen är relativ till funktion. Sanningen definieras där temporärt och kommunikation och språk fungerar som sanningskonstruktör ${ }^{8}$. Det viktiga i sammanhanget är dock inte att stanna vid diskussioner av sanning och världsbildskonstruktioner i generell mening, utan snarare att påpeka att Dewey ansåg att estetiska och konstnärliga upplevelser och erfarenheter hade en unik potential att erbjuda en holistisk och ny förståelse av världen. Skälet för att jag skriver "upplevelser och erfarenheter" är att på engelska finns inga distinktioner mellan dessa då båda översätts bäst med “experiences”. Vad menar han då med att estetiska och konstnärliga "experiences" till skillnad från andra typer av erfarenheter/ upplevelser, kan vara holistiska? Min läsning av detta som även korresponderar med Deleuze och Guattari (som jag återkommer till), är att estetiska erfarenheter/upplevelser innebär att man öppnar sig för det oväntade och skalar bort analytiska filter vilket gör att nya åskådliggöranden kan framstå som begripliga på nya och oväntade sätt. Konst som kommunikation blir således ett viktigt demokratiskt och pedagogiskt verktyg för att kunna bryta genom stängsel mellan olika sanningskonstruktioner och möjliggöra empatiska möten.

Jag fick något som kanske var en estetisk upplevelse av att läsa Deweys Art as Experience`, framför allt kapitlet «The Challenge To Philosophy». Dewey gjorde upp med Kants och Adornos mer finkulturella och exkluderande syn på estetik som läran om konsten och dess funktion och kvalité. I mångt och mycket kände jag att Deweys återtagande av den estetiska erfarenheten var precis 
det jag letade efter. Men fortfarande gnagde den grundläggande frågan "Hva er estetikk?". Dewey definierar aldrig estetik utöver att han använder begreppet i en mängd olika sammanhang. Därigenom kan jag däremot utläsa någon form av definition. Den definitionen är dock inte särskilt entydig eller koncis, vilket jag efterhand insåg var rimligt: Med tanke på att alla kulturer i alla tider har använt sig av estetiska uttryck genom väggmålerier, dans, musik etc. är det rimligt att anta att estetiska och konstnärliga verksamheter utgör en viktig del gällande det att vara människa. Och om estetik är ett fenomen som är viktigt i vad som definierar oss som människor, vore det konstigt om det kan beskrivas i några få meningar. Estetik borde vara lika svårt att förklara som kärlek eller krig . . . Trots detta började jag söka vidare - framför allt efter något som på ett bättre sätt kopplade konst och konstnärlig praxis till estetik och estetiska upplevelser.

På vägen hade jag turen att stöta på Pierre Bourdieu ${ }^{\text {Io }}$ som jag omfamnade ett tag i ett försök på att se konsten som social institution snarare än som psykosocial existentiell företeelse enligt Dewey. Bourdieu skapar en fantastisk begreppsvärld där konsten och estetiska preferenser ingår i ett symbolkapitalistiskt spel om definitionsmakt. Konst blir med andra ord en informell institution som säkrar att vissa får makt över den goda smaken genom att de besitter kulturellt kapital, medan andra inte har tillgång till sådant kapital. Bourdieus verktygslåda av begrepp ligger tillsammans med Dewey som ett klokt och viktigt raster bakom de tankar som har format den text jag nu skriver. Detta är dock inte tillräckligt. För att fylla i rastret kommer jag även att använda mig av Deleuze och Guettari; framförallt deras sista bok What is Philosophy ${ }^{\mathrm{II}}$.

Hänger du med? Nu håller jag omärkligt på att glida in i den där vita tröjan - utan att jag ens kände av det blev språket och texten klassiskt retorisk och utan den koppling mellan form och innehåll som jag önskar mig. Varför utelämnade jag upplevelsen av solnedgången som ställer en mållös inför världen eller känslan av att simma i stora vågor? När det sköljer över mig så jag knappt kan andas, men ändå känner hur muskler bryts mot vattnets krafter, när jag i bråkdelen av en sekund är en delfin som dyker under och kan simma i all oändlighet under vatten. Så skriver Dewey om 
som estetiska erfarenheter/upplevelser. Han vill ta tillbaka estetiken till vardagen och då ingår även upplevelser av naturen. Det är då det blir riktigt svårt . . Är naturen konst då? Dewey har kritiserats för att i Art as Experience ${ }^{\mathrm{I} 2}$ definiera konsten som estetisk upplevelse - men är det verkligen det han gör? Jag återkommer till det.

Det estetiska i estetisk kommunikation ska förstås i relation till tilllblivandet av de meningsskapande mellanrum vars blivande inte enbart kan förklaras genom logiskt rationellt verbalspråk. I enlighet med såväl Dewey som Deleuze och Guattari är en del av konstens uppgift att (re)konstruera oväntade och nya förståelser av världen i dessa meningsskapande mellanrum.

För såväl Dewey som Bourdieu bestäms ett ords betydelse av dess användning. Detsamma gäller för orden estetik och konst vad de betyder bestäms av hur de används, av vem de används och när de används. De skapas med andra ord i det kommunikativa spelet - eller "språkspelet" som Ludwig Wittgenstein ${ }^{\mathrm{r} 3}$ kalllade detta fenomenet. Det innebär också att ett ord som används mycket alltid kommer att användas på en mängd olika sätt och att ordets betydelse kommer att ändra sig genom olika tider och i olika kontexter. När Dewey beskriver konst som upplevelse/erfarenhet så tror jag inte det ska förstås som att han menar att konst kan definieras eller ens värderas utifrån huruvida den ger en speciell upplevelse. Så som det ger mening för mig så betyder Deweys utsaga att en väsentlig komponent av konsten är den erfarenhet/ upplevelse som den ger/kan ge/är tänkt att ge. Upplevelse/erfarenhet är som tidigare nämnt centralt i Deweys teorier kring lärande och kommunikation och dessa begrepp kan förstås som ömsesidigt beroende av varandra. Erfarenhet och upplevelse leder till lärande -> Lärande ger erfarenhet -> Kommunikation kan förstås som delande av erfarenhet $\rightarrow$ Delande av erfarenhet/kommunikation leder till lärande . . Begreppen ska enligt Dewey däremot inte bara förstås genom dess användning, men också genom vad ordet gör - vilken effekt det har. Denna pragmatiska inställning delar han med Deleuze och Guattari ${ }^{14}$.

Deleuze och Guattari ${ }^{15}$ skriver inte specifikt om begreppet estetik, men deras teorier om konst har format mina tankar om estetisk kommunikation i hög grad. De frågar sig vad konstens 
uppgift och funktion är och identifierar tre mänskliga verksamheter som på olika sätt hjälper människan att förstå och förhålla sig till världen: Vetenskap, filosofi och konst. Syftet med vetenskap är att producera kunskap genom att plocka isär (delar av) verkligheten i små bitar så att vi kan se vad världen är uppbyggt av och hur saker och ting hänger ihop. Sedan byggs modeller och vi kan förstå världen på nya sätt. Att peta isär och förstå bitarna i förhållande till helheter innebär också att det är möjligt att påverka och ändra verkligheten.

Filosofins roll i mänsklighetens strävan efter att förstå är snarlik, och samtidigt fundamentalt olik vetenskapens: Filosofins uppgift är att komma på, och lansera koncept. Med koncept menas inte ord eller begrepp utan snarare tankefigurer som kan öppna upp för nya sätt att tänka, kommunicera och förstå på. Ett exempel Deleuze och Guattari använder är Descartes mening Cogito ergo sum ("Jag tänker, alltså är jag") som öppnade upp för ett nytt sätt att förstå vad en människa är och vari gränsen mot det mänskliga kan ligga. Med konceptet öppnades det upp för nya samtal och nya förståelser av vad det innebär att vara människa.

Vad är då konstens roll? "Att bringa glädje och njutning till människan genom skönhet och fernissa självklart” skulle kanske någon säga. Andra skulle kanske säga att det är ett sätt att uttrycka sig och kunna få utlopp för sin kreativa energi. Andra skulle kanske hävda att konsten är samhällets spegel som behövs för att kritisera allt som behöver åtgärdas - för att skapa ett bättre samhälle. Som tidigare nämnts finns det en hel gren inom filosofin för denna typ av diskussioner och sådana uppfattningar återfinns i filosofin såväl som i vardagsdiskurser. Och konsten har självklart en mängd olika uppgifter och funktioner. Det Deleuze och Guattari lyfter fram som det mest väsentliga är dock inga av de ovannämnda funktionerna. För dem är konstens viktigaste uppgift att visa upp (delar av) världen på nya och oväntade sätt. Genom att möta konst kan människan bli förvånad och upptäcka nya sanningar som visar sig för dem och som det är svårt att värja sig emot då konsten har förmågan att tala förbi förnuftet och till hela människan. Jag föreställer mig att konsten dels har utvecklats som ett sätt för människor att upptäcka saker som inte platsar i 
den livsåskådning hen har och dels som ett sätt att få andra att se världen som en själv gör. Att manipulera sina medmänniskor . . .

\section{Sats 2-Menuett}

Konst är manipulation. Hallå där!? Sådant kan väl inte vara konstens uppgift. Att manipulera är oschysst ju . . .

Varje gång jag presenterar min idé om konst som manipulation får jag liknande reaktioner: "Jag förstår vad du menar, men kan du inte hitta ett annat ord? Manipulation låter så negativt.” Jag håller med. Manipulation är inget jag heller önskar att bli utsatt för i vardagen. Men som jag hoppas visa så småningom, så är det just manipulationen jag söker i konstupplevelser. För att förklara vad jag menar behöver jag gå ett par steg tillbaka. Konsten tar utgångspunkt i en lekfylld manipulation med förväntningar ${ }^{16}$.

Den norska filosofen Arne Næss hade, i likhet med Deleuze, den gamle judiska filosofen Spinoza som sin största inspirationskälla. Varför det är relevant att han var jude? Jo det ska jag förklara: Spinoza levde på I 600-talet i Amsterdam och var glasblåsare ${ }^{\mathrm{I} 7}$. Att han även var filosof och skrev filosofiska texter var inte något han ville vara anställd för. Han ville skriva fritt och avböjde därför att bli anställd som lärare. Det han skrev om var Gud. Men inte den gud som de judiska församlingarna ansåg sig läsa om i de heliga skrifter. Spinoza blev kallad panteist och hedning och blev utstött från det judiska samhället. Skälet var att han beskrev en gud som inte var en person. Spinozas gud var Alltet som vi alla är en pytteliten del av, men som också rymdes i varje enskild varelse i sin totalitet. Enligt Spinoza innebär det att alla hänger ihop och är en del av detsamma - nu, förr och i framtiden. Att skada någon eller något, eller göra orätt mot sig själv eller andra eller annat blir att gå mot sin natur. Och nu - efter denna lilla promenad på en historisk sidoväg, kommer jag tillbaka till Næss som inledde detta stycket. Arne Næss tog avstamp i Spinozas idé hur allt hänger ihop och initierade en riktning inom filosofin som kallas ekosofi. Ekosofin tar sin utgångspunkt i Spinozas tankar för att skapa ett tankeuniversum där människan inte kan skilja mellan sig själv och naturen och därför inte kan utnyttja naturen 
på naturens bekostnad utan att våldföra sig på sig själv. Ett tankeverktyg Næss introducerar är possibilismen.

Possibilism innebär en grundinställning att allt är möjligt. Även om mycket är osannolikt och aldrig, vad vi vet, har inträffat i historien innebär det inte att det inte skulle kunde hända. Næss tar ett exempel där du kan tänka dig att du går i skogen en dag och ser en flygande sten. Många skulle nog säga att det inte hände att det var något som du inbillade dig. Trots allt - alla vet ju att en sten inte kan flyga. Jag kan föreställa mig massor med saker som en människa som levde för ıoo år sedan skulle förneka på samma sätt om hen dök ner i Stockholm i år 2018 på fem minuters gästvisit. Det gäller med andra ord att vara redo för det oväntade och inte fastna i snäva förväntningar. Och just förväntningar är centralt i all estetik, konst och lärande - till och med så centralt att jag anser att en definition av konst kan låta: «Konst är medveten manipulation genom funktionella brott mot förväntningar och lek med konventioner».

\section{Sats 3 - Scherzo}

$\mathrm{Nu}$ har jag pratat om konst och estetik lite om vartannat. Sammanblandningen är inte helt genomtänkt, men nästan. Det estetiska och konsten är, i en pragmatisk mening, lika nog för att det känns meningsfullt att beskriva dem som nästan synonymer trots att de inte alltid är samma sak som jag redan har beskrivit. Det flesta av de aktiviteter vi håller på med i så kallade estetiska ämnen eller i «estetiska lärprocesser», förhåller sig till någon konstart som idé, förlaga eller referenspunkt. Att som i Norge prata om kunstfagsdidaktikk (konstämnernas didaktik) ger på så sätt kanske mer mening än att prata om estetiska ämnen då det i stor grad handlar om att undervisa i och lära sig om konst, med konst, i konst och genom konst som Lars Lindström skriver ${ }^{18}$. Konsten ska då förstås på olika sätt - som institution, som aktivitet, som artefakt och kommunikationsform. Att musik till exempel kan vara konst och erbjuda estetiska upplevelser och erfarenheter är två sidor av samma mynt.

Begreppet estetisk kommunikation är mitt försök på att uppfylla det deleuzianska kravet på filosofi: att komma fram med begrepp 
som ger oss möjligheter för att tänka på nya sätt. Begreppet uppkom ur en frustration över existerande närliggande begrepp så som Det vidgade textbegreppet, Multimodalitet och Multiliteracy ${ }^{19}$ liksom Estetiska lär(o)processer. Begreppet estetisk kommunikation öppnar för att fokusera på det som är viktigt i lärande och undervisning: Kunskapsproduktion - hur meningsskapande sker i interaktion mellan människor. Att prata om estetisk kommunikation istället för de begrepp jag var frustrerad över innebär också ett brott mot en traditionell kunskapsöverföringspedagogik där kunskap betraktas som statisk och färdig och där eleven är den enda som ska lära sig. Estetisk kommunikation ska med andra ord betraktas som en didaktisk term som lägger vissa premisser för vad en önskvärd undervisning bör innebära när konstruktion av kunskap sker inom utbildningsinstitutionella ramar. Vissa delar av detta har jag redan nämnt: Undervisning i, om, med och genom konst ska vara lekfullt, experimenterande och förhålla sig till konventioner och förväntningar för att sedan vrida på dem, och öppna för nya insikter och varianter på kunskap genom sublim manipulation $^{20}$. För att åstadkomma dessa grundläggande aspekter av vad som kan kallas konstens väsen, krävs medvetandegörande. En förutsättning för att kunna leka med konventioner är att konventionerna är kända, och att den som ska experimentera har koll på de effekter konventionerna bidrar till. Hur skapas en läskig stämning i en film genom ljud? Hur reagerar vi på en närbild av ett gråtande barn? Vilka kameratekniker gör att filmen känns stressig? Hur ljussätts lycka? Frågorna är outtömliga och kan aldrig besvaras på enkla och entydiga sätt då de ändras från genre till genre, tidsepok till tidsepok, kultur till kultur etc. Men genom erfarenhet och ständigt medvetandegörande kan såväl upplevelse av kulturuttryck som skapande utvecklas till viktiga bidrag i den egna och andras förståelser av samhället, sig själv och livet.

Då en grundpremiss i estetisk kommunikation är att lärande snarare handlar om utveckling och skapande av kunskap, snarare än om upprepning av kunskap, blir det av större vikt att identifiera vilka medvetandedimensioner som kan utvecklas och experimenteras med än att definiera vilket kunskapsinnehåll som ska behandlas. Genom olika publikationer ensam och tillsammans 
med Cecilia Ferm Almqvist har följande aspekter växt fram som funktionella fokuspunkter i det estetiska kunskapandet:

- Medvetande om dig själv som subjekt - dina (potentiella) roller och estetiska kompetenser

- Medvetande om och uppmärksamhet mot andras roller och estetiska uttryck

- Medvetande om sammanhanget där kommunikationen sker

- Medvetande om intenderade och uppfattade funktioner av estetisk mediering och dess potentiella variationer

Dessa är sammanvävda och måste förstås i relation till andra krafter i kommunikationen så som:

- Förväntningarna från alla involverade i kommunikationen

- Drivkrafter som driver och motverkar kommunikationen

- Varje involverad individ och grupps partikulära erfarenheter

- Diskursiva maktstrukturer, historier och doxa.

Dessa dimensioner kan ses som en checklista eller inspirationslista för att arbeta processuellt eller med produkt i såväl konstnärliga ämnen som i ämnen där det estetiska fungerar mer som gestaltande eller processuella verktyg för kunskapsbildning och meningsskapande. Jag ska förklara vad jag menar:

För att ta de fyra medvetandedimensionerna först så skulle de kunna delas upp på olika sätt, och på sätt och vis är de omöjliga att dela upp då de är just dimensioner av samma företeelse. För att kunna bli medveten är det ändå funktionellt att identifiera olika fokuspunkter och tills jag eller någon annan kommer på ett bättre raster att fokusera genom så fungerar dessa. Det är viktigt att komma ihåg att ovannämnda punkter ingår för alla i estetisk kommunikation; det är med andra ord inte bara eleven som ska bli medveten; alla ingår i kommunikationen - medmusikanter, publik, lärare, elev, publicist, målare . . . Listan kan fortsätta i oändlighet. Som didaktiskt begrepp är det dock de som utsätter sig för att utvecklas som kommer ta itu med att reda ut vad detta betyder i deras (kun-/menings-)skapande. 
Den första, Medvetande om dig själv som subjekt - dina (potentiella) roller och estetiska kompetenser, handlar om att titta sig själv i spegeln och fråga sig "vem är jag, vad vill jag säga, vilka medel har jag till förfogande för att nå fram med mitt budskap och hur reagerar jag när jag utsätts för dessa medel? Varför då? Vilka kommunicerar jag med och vad är min roll i den kommunikationen?”. Detta kräver en akt av introspektiv reflektion där varje deltagare ställer sig nyfiken inför sig själv och försöker ta reda på sin position, vilka drivkrafter som styr ens estetiska preferenser och önskningar om att säga något. Det kan se ut som om detta kräver att det estetiska budskapet måste vara klart definierat när man går in i ett skapande eller gestaltande process, men det är viktigt att vara medveten om att denna reflektionsprocess ofta ska och bör vara en reflektion som följer med fortlöpande i processen som ett parallellt analytiskt medvetande till det skapande - inte olikt vad Schön ${ }^{21}$ kallar "reflection in action". Enligt Schön är detta något konstnärer och hantverkare gör tillsammans med "reflection on action" där de reflekterar över sina handlingar innan eller efter själva aktionen sker. Så som du och jag gör just nu. Så som jag ser det är det inte nödvändigt att hålla fast i det analytiska reflekterande medvetandet hela tiden, men det som är viktigt är att det registreras vad som sker så att det genom ett växelspel mellan att tänka på handling och i handling kan uppstå en förståelse för vad som sker.

Det kan finnas en fara i att aldrig låta det analytiska släppa taget, och därigenom förstöra det intuitiva, impulsiva, nyfikna, nyskapande och intressanta. Det gäller med andra ord att växla mellan att släppa taget och att sätta på den inre videokameran som registrerar vad som händer och ger möjlighet för att analysera ens eget agerande och reaktion.

Medvetande och uppmärksambet mot andras roller och estetiska uttryck, är en vidgning av den navelskådande första punkten. När jag uppfattar hur jag reagerar på andras uttryck är det $\mathrm{i}$ denna medvetandedimensionen viktigare vad den andra gör och hur den andra verkar reagera och uppfatta det som sker utifrån den personens uppgift och roll i situationen. Det handlar med andra ord om att ställa frågor som "Vad verkar hen vilja säga? Hur går hen tillväga för att nå fram? Vilka verktyg har hen tillgång 
till och vilka väljer hen? Hur reagerar jag i förhållande till hur andra reagerar?" Det blir med andra ord dels en psykologisering av den andre och dels en analys av spänningsfältet som uppstår i mötet mellan en själv och den andre.

I den tredje medvetandedimensionen medvetande om sammanhanget där kommunikationen sker, vidgas fokus för uppmärksamheten ytterligare. Kommunikationen sker självklart inte i ett vakuum. Tid och rum är inte enbart kulisser för kommunikationen, de är vitala premissleverantörer för vilken kommunikation som kan hända, vad det är tillåtet att säga, vad som framstår som en kliché, vad som är självklart och passande eller avigt och opassande. Det är skillnad på att stå naken på en teaterscen eller på en scen i en skolas aula till exempel. Det är skillnad på att spela Death metal i en klubblokal eller i St Peterskyrkan i Vatikanstaten ... . Det är skillnad på att dansa breakdance 2016 i Stockholm och att göra det 1972 i Bronx. Platsen, kulturen och tiden formar hela kommunikationens förutsättningar och betydelse och det är därför oerhört viktigt att vara medveten om detta när man leker med manipulation i estetisk kommunikation.

Den sista medverkandedimensionen, medvetande om intenderade och uppfattade funktioner av estetisk mediering och dess potentiella variationer, flyttar fokus från deltagare och sammanhang till själva innebörden av kommunikationen. Denna dimension innehåller de tre föregående, men också alla möjligheter som inte (än) är utforskade. För att bryta ner meningen handlar den om att försöka att komma åt vilka intentioner som skulle kunna ligga bakom ett estetiskt uttryck - vad förväntar sig avsändaren att sådana gestaltningar ska åstadkomma? Denna punkt handlar även om hur sådana gestaltningar upplevs och uppfattas, samt hur de skulle kunna uppfattas och upplevas. Johnny Wingstedt ${ }^{22}$ talar om musikens berättandefunktioner i förbindelse med filmoch spelmusik i sin avhandling. Han refererar till temat från hajen t.ex som har vissa musikaliska parametrar som signalerar fara i vår kultur. Som deltagare $\mathrm{i}$ kulturen känner vi till konventionernas berättandefunktioner och kan förhålla oss till dem. I den didaktiska teorin om estetisk kommunikation är det på liknande sätt den mediespecifika gestaltningens konventioner när det gäller vad den signalerar som är i fokus. Med "dess potentiella variationer" 
menar jag att det skulle kunna vara annorlunda - som jag tidigare förklarade med referens till Arne Næss possibilism. Att föreställa sig möjliga variationer av vad en kliché kan betyda, skapa eller göra kan öppna för nya sätt att uttrycka något och skapa mening som publik. I fenomenologin finns en metodologisk princip om att för att undersöka ett fenomen föreställa sig alla möjliga variationer på vad fenomenet skulle kunna vara - för att utforska fenomenets gränser och identifiera dess kärna. I estetisk kommunikation är ett liknande förhållningssätt en farbar väg till att som det heter nu för tiden - tänka utanför boxen.

Tillsammans utgör dessa medvetandedimensionerna i kombination med principerna om att leka med att manipulera förväntningar och possibilism en möjlig didaktisk ram för att lägga till rätta för lärande i, genom, om och till konsten. Det är dock viktigt att alltid ta med i beaktande de andra krafterna jag listade här ovan för att kunna optimera den estetiska kommunikationen i ett didaktiskt sammanhang:

Förväntningarna frän alla involverade $i$ kommunikationen har jag redan nämnt i förbindelse med förväntningar på gestaltning, tolkning och innebörd, men förväntningar har vi på allt, och om en elevgrupp kommer till en lektion i musik med förväntningen att de ska få lyssna på låtar från Melodifestivalen och möts med att skulla experimentera med atonala ljudkompositioner så kan det uppstå problem. På samma sätt påverkar det läraren om hen förväntar sig något specifikt och detta bryts emot. I några klassiska experimentella studier från I960 och -70-talet får lärare besked om att gruppen de ska undervisa är antingen ovanligt duktiga eller ovanligt hopplösa - trots att grupperna är utvalda enligt principen att de ska vara en genomsnittlig grupp. I loppet av några månader blir lärarens förväntningar uppfyllda: Det blir en ganska obehaglig självuppfyllande profetia där läraren genom att ha tro sig veta saker kan forma eleven till att bli just $\operatorname{det}^{23}$. Ett annat exempel på förväntningarnas oerhörda kraft är placebo. Genom enbart att förvänta att det är medicin vi får kurerar vi oss själva. Ingen i musiksalen kan undvika sina förväntningar skriver Estelle Jorgensen ${ }^{24}$ och syftar på hur människan alltid är begränsad av vad hen tror att en aktivitet skulle kunna innehålla. För att koppla till Arne Næss igen så skulle jag hävda att det är omöjligt 
att jobba mot ett mål som man inte kan föreställa sig. Om man inte kan föreställa sig att bli ingenjör så väljer man inte vägar som leder till att bli ingenjör. Om man inte kan föreställa sig att en tårta kan få en minister på fallrepet så som Makode Linde ${ }^{25}$ gjorde så skapar man inte omskakande tårtkonst. I och med konstens syfte att skapa det okända eller oförväntade, tränas förmågan att ha varierade och öppna förväntningar, vilket i sin tur kan leda till såväl ett bättre liv för den enskilde som ett mer tolerant samhälle. Att vara rädd för det okända eller fast i trånga mönster har visat sig vara en viktig ingrediens i t.ex. främlingsfientlighet och kulturell protektionism ${ }^{26}$. Nu ringer varningsklockor: Jag vill verkligen varna för att tro att konst innebär något gott per automatik. Konstnärliga aktiviteter är som alla andra aktiviteter alltid laddade med värden, men det är i varje enskild (konstnärlig) aktivitet värdet visar sig. Konstnärliga och estetiska aktiviteter kan med andra ord användas för att förtrycka en befolkning eller förföra en församling i massuggestiv manipulation - vilket många despoter har förstått. Min poäng är att genom deltagande i konst finns en potential för att möta och spränga egna skygglappar. Denna potential borde vara en stark didaktisk ådra till inspiration.

Varför är vi där? Varför har vi valt att sätta oss i en lärandesituation? Vad har vi med oss in och vad vill vi ha ut av situationen? I faktorerna, Drivkrafter som driver och motverkar kommunikationen och Varje involverade individ och grupps partikulära erfarenheter vill jag lyfta fram just dessa ramfaktorer som möjliggör att estetisk kommunikation kan bli en fruktbar lärandesituation. Varje enskild människa i kommunikationen tar med sig olika förutsättningar, inte bara genom sina förväntningar, men lika mycket genom erfarenheter - det som har gjort oss till den vi är; vår habitus $^{27}$, och våra drömmar som ger kraft, motivation och inspiration att ta oss an utmaningar och uppgifter och göra dem till våra egna. Uppmärksamheten mot sig själv och den andre i kommunikationen måste därför fråga just detta: Vem är du, vem är jag (levande charader), och vem vill vi vara? Den optimala lärandesituationen är den där en gemensam vision delas och lärandet ses på som ett gemensamt projekt där arbetet delas och alla får ut något av situationen. Men oftast är det inte så och då måste personerna ändå mötas för att få det att fungera. I sin avhandling benar Moira von 
Wright ut skillnaderna mellan att bemöta en elev som ett "vad" eller som en "vem". Det är skillnad på att betrakta en elev som en uppsättning (bristande) kompetenser (vad) och att intressera sig för hela elevens person, hens erfarenheter, liv, behov, önskningar och drömmar. I estetisk kommunikation är då ett strävansmål att mötena ska vara ömsesidigt nyfikna och respektfulla så att det lekfulla meningsskapandet får så goda förutsättningar som möjligt. Detta kräver även att läraren är öppen och inser att hen inte är färdigformad som människa, men att alla i kommunikationen bidrar med olika delar för att åstadkomma något nytt. Det innebär dock inte att läraren abdikerar - hen har fortfarande en helt annan roll och annan typ av ansvar i undervisningen än eleven ${ }^{28}$. Detta leder osökt texten till min sista poäng innan jag slutar att skriva denna högerhänta text: Diskursiva maktstrukturer, historier och doxa. För att vara helt ärlig så betyder det bara att det är viktigt att komma ihåg resten också. Att lyfta blicken och fråga sig hur det blev på det här viset och hur det skulle kunnat vara om det inte var så. Hur hade musiken låtit om Hitler vann kriget? Hur kom det sig att musikbranschen blev så mansdominerad? Hur skulle konstvärlden se ut om det inte fanns statligt stöd till museer? Är det nödvändigt att alla barn ska gå i skola? Borde inte egentligen barn ha rösträtt på tal om det? Vem ska bestämma vad som ska läras i skolan? Är inte skolan i grunden en maktstruktur som förtrycker individens frihet och upprätthåller samhällets status quo där vissa är privilegierade på andras bekostnad? Eller är det bara PK-forskaren Ketil som skriver så för att bli klar någon gång så han kan sluta att skriva med en hand?

Ingen idé är någonsin färdig, uttömd och klar, men texter är som musikaliska kompositioner som ger intryck av att vara en genomtänkt helhet med en början, mittdelar och slut. Strukturen jag har valt, sonatsatsformen, är en sådan klassisk struktur. Nu tänkte jag bryta med förväntan om det och snarare tona ut som i en poplåt från 70-talet. Som när musikerna fortsätter att spela medan volymen sänks, är det min förhoppning att du som läser - och jag - fortsätter att tänka på estetisk kommunikation och didaktisk manipulation att vi kommer vidare och ser något nytt och oväntat.

Jag har åkt snowboard. Vänster arm är ur led och tryggt inslaget i gips, och när fåglar börjar en ny låt utanför, har det gått 7 månader sedan du började läsa den här artikeln. Eller om det var 
jag som började skriva? Sensommar har blivit vår och mitt högra ringfinger trycker ner den sista tangenten nu...n $\mathrm{u} \ldots \mathrm{n} \mathrm{u} \ldots \mathrm{n}$ $\mathrm{u} \ldots \mathrm{nu}$... n u ...

\section{Slutnoter}

I. Daniel Ericsson, Kreativitetsmysteriet: Ledtradar till arbetslivets kreativisering och skrivandets metafysik, red. Ekonomiska forskningsinstitutet vid Handelshögskolan i Stockholm. (Stockholm: Ekonomiska forskningsinstitutet vid Handelshögskolan. (EFI), 200 I).

2. Framförallt John Dewey, i Art as Experience (New York: Perigee, 2005); John Dewey, i Democracy and Education: An Introduction to the Philosophy of Education (The Macmillan company, I9I6).

3. Arne Næss \& Per Ingvar Haukeland, Livsfilosofi: et personlig bidrag om følelser og fornuft (Oslo: Universitetsforlaget, I999).

4. Gilles Deleuze \& Felix Guattari, What is philosophy? (London: Verso, I994); Gilles Deleuze, Spinoza, practical philosophy (San Francisco: City Lights Books, I988); Gilles Deleuze og Felix Guattari, A thousand plateaus: capitalism and schizophrenia (London: Continuum, 2002).

5. Ketil André Thorgersen \& Eva Alerby, «One Word to Rule Them? The Word Aesthetics in Curricula for the Swedish Compulsory School», Utbildning och Demokrati I4, nr. I (2005): 63-79.

6. Richard Shusterman, "The End of Aesthetic Experience», The Journal of Aesthetics and Art Criticism 55, nr. I (I997): 29-4I.

7. Det var inte de själva som kallade sig pragmatiker - faktum är att olika inom pragmatismen försökte sig på att skapa olika epitet, men "Pragmatismen" är vad som har levt kvar.

8. Larry A. Hickman, Pragmatism as post-postmodernism: Lessons from John Dewey, bd. 2I (Fordham Univ Press, 2007).

9. Dewey, Art as Experience.

Io. Pierre Bourdieu, Distinction: a social critique of the judgement of taste (London: Routledge, I984); Pierre Bourdieu og Randal Johnson, The field of cultural production: essays on art and literature (Cambridge: Polity, I993).

I I. Deleuze \& Guattari, What is philosophy? 
I2. Dewey, Art as Experience.

I3. L. Wittgenstein, Philosophical investigations... Transl. by GEM Anscombe (Blackwell, 1963).

I4. Även om Deleuze inte själv kopplade sig till en tanketradition från pragmatismen finns det flera beröringspunkter. Se t.ex. Simone Bignall, Sean Bowden, og Paul Patton, Deleuze and Pragmatism (Routledge, 20I4).

I 5. Deleuze \& Guattari, What is philosophy?

I6. Ketil Thorgersen, «Music Education as Manipulation: A Proposal for Playing», Submitted; Staffan Carlshamre, «Art as Manipulation», 2005, http://people.su.se/ snce/estetikseminariet/texter/ArtManipulation.pdf.

I7. Benedictus de Spinoza \& Dagmar Lagerberg, Etiken (Stockholm: Thales, 200I).

I 8. Lars Lindström, "Aesthetic Learning About, In, With and Through the Arts: A Curriculum Study", International Journal of Art \& Design Education 3 I, nr. 2 (I. juni 20I 2): I66-79.

I9. Ketil Thorgersen, «Unspoken Truths: About Aesthetics in Swedish Schools» (Licentiatavhandling, Luleå tekniska universitet, Musikhögskolan i Piteå, 2007).

20. Ketil Thorgersen, Music Education as Manipulation: A Proposal for Playing (Frankfurt, 201 5 ).

2I. Donald A. Schön, The reflective practitioner: how professionals think in action (Aldershot: Arena, 2003).

22. Johnny Wingstedt, «Making music mean: on functions of and knowledge about narrative music in multimedia» (Department of music and media, Luleå University of Technology, 2008).

23. Se t.ex. Lee Jussim \& Kent D. Harber, «Teacher expectations and self-fulfilling prophecies: Knowns and unknowns, resolved and unresolved controversies», i Personality and social psychology review 9, nr. 2 (2005): I 3 I-5 5; Jere E. Brophy, «Research on the self-fulfilling prophecy and teacher expectations.», i Journal of Educational Psychology 75, nr. 5 (oktober I983): 63 I-6I.

24. Estelle Ruth Jorgensen, The art of teaching music (Indiana University Press, 2008). 
25. Makode Linde används här som ett exempel på samhällsomvandlande konst genom att han $20 \mathrm{I} 2$ på en vernissage på Moderna muséet i Stockholm fick publiken att skära upp en tårta i människostorlek formad som en stereotyp afrikansk kvinnofigur - en såkallad "Black face" med konstnären skrikande inuti.. Kulturministeren skar en bit och blev således en del av konstverket och möttes med krav från olika grupper att avgå. «Makode Linde. Nu får tårtan ett sammanhang», i DN.SE, 2I. mai 20I2, http://www.dn.se/kultur-noje/ konst-form/makode-linde-nu-far-tartan-ett-sammanhang/.

26. Se t.ex.Anders Hellström \& Tom Nilsson, «'We Are the Good Guys' Ideological Positioning of the Nationalist Party Sverigedemokraterna in Contemporary Swedish Politics», Ethnicities Io, nr. I (3. januar 2010): 55-76.

27. Pierre Bourdieu \& Loïc J. D. Wacquant, An invitation to reflexive sociology (Chicago: University of Chicago Press, I992).

28. Jeg behandlar dessa aspekt mer i Ketil Thorgersen, «Musik som estetisk kommunikation i fritidshemmet», i Meningsskapande fritidshem: studio som arena för multimodalt lärande, bd. s. 53-8 I, Lund: Studentlitteratur, 2013); Cecilia Ferm \& Ketil André Thorgersen, "Aesthetic communication in music education - Student's awareness» (The seventh international symposium on the philosophy of music education, London, Canada, 2007).

\section{Referenser}

Bignall, Simone, Sean Bowden, \& Paul Patton. 20I4. Deleuze and Pragmatism. New York/London: Routledge.

Bourdieu, Pierre. I984. Distinction: a social critique of the judgement of taste. London: Routledge.

Bourdieu, Pierre, \& Randal Johnson. I993. The field of cultural production : essays on art and literature. Cambridge: Polity.

Bourdieu, Pierre, \& Loï J. D. Wacquant. I992. An invitation to reflexive sociology. Chicago: University of Chicago Press.

Brophy,JereE. I983. "Research on the self-fulfilling prophecy and teacher expectations.» Journal of Educational Psychology 75 (5):63 I6I. https://doi.org/http://dx.doi.org/I0.I037/0022-0663.75.5.63 I. 
Carlshamre, Staffan. 2006. "Art as Meaning and Manipulation». I Kvantifikator för en Dag - Essays dedicated to Dag Westerstähl on his sixtieth birthda. Göteborg: Filosofiska institutionen, Göteborgs universitet. http://www.phil.gu.se/posters/festskrift 3/carlshamre. pdf.

Deleuze, Gilles. I988. Spinoza, practical philosophy. San Francisco: City Lights Books.

Deleuze, Gilles, \& Felix Guattari. I994. What is philosophy? London: Verso.

- 2002. A thousand plateaus: capitalism and schizophrenia. London: Continuum.

Dewey, John. 1916. Democracy and Education: An Introduction to the Philosophy of Education. The Macmillan company.

- 2005. Art as Experience. New York: Perigee.

Ferm, Cecilia, \& Ketil André Thorgersen. 2007. "Aesthetic communication in music education - Student's awareness». ISPME conference . London, Canada.

Hellström, Anders, \& Tom Nilsson. 20ıо. "'We Are the Good Guys' IdeologicalPositioning of the NationalistParty Sverigedemokraterna in Contemporary Swedish Politics». Ethnicities Io (I):5 5-76. https://doi.org/IO.I I77/I4687968093542I4.

Hickman, Larry A. 2007. Pragmatism as post-postmodernism: Lessons from John Dewey. Bd. 2I. Fordham Univ Press.

Jorgensen, Estelle Ruth. 2008. The art of teaching music. Chicago: Indiana University Press.

Jussim, Lee, \& Kent D. Harber. 2005. «Teacher expectations and self-fulfilling prophecies: Knowns and unknowns, resolved and unresolved controversies». Personality and social psychology review $9(2):$ I 3 I-I 55 .

«Makode Linde. Nu får tårtan ett sammanhang». 20I 2. DN.SE. 2I. mai 20I2. http://www.dn.se/kultur-noje/konst-form/makodelinde-nu-far-tartan-ett-sammanhang/.

Næss, Arne, \& Per Ingvar Haukeland. I999. Livsfilosofi : et personlig bidrag om følelser og fornuft. Oslo: Universitetsforl. 
Schön, Donald A. 2003. The reflective practitioner : how professionals think in action. Aldershot: Arena.

Shusterman, Richard. 1997. "The End of Aesthetic Experience». The Journal of Aesthetics and Art Criticism 55 (I):29-4I.

Spinoza, Benedictus de, \& Dagmar Lagerberg. 200 I. Etiken. Stockholm: Thales.

Thorgersen, Ketil André. Submitted. «Music Education as Manipulation : A Proposal for Playing».

- 2007. «Unspoken Truths: About Aesthetics in Swedish Schools». Licentiate Thesis, Luleå tekniska universitet, Musikhögskolan i Piteå.

. 2013. "Musik som estetisk kommunikation i fritidshemmet». I Meningsskapande fritidshem : studio som arena för multimodalt lärande. Bd. s. 53-8I. Lund : Studentlitteratur.

- 2015. Music Education as Manipulation: A Proposal for Playing. ISPME conference. Frankfurt.

Thorgersen, Ketil André, \& Eva Alerby. 2005. "One Word to Rule Them? The Word Aesthetics in Curricula for the Swedish Compulsory School». Utbildning och Demokrati I4 (I):63-79.

Wingstedt, Johnny. 2008. «Making music mean: on functions of and knowledge about narrative music in multimedia». Piteå: Department of music and media, Luleå University of Technology.

Wittgenstein, L. I963. Philosophical investigations... Transl. by GEM Anscombe. Blackwell. 